\title{
Pedagogias da saudade: a formação histórica de consciências e sensibilidades saudosistas. A vida e o trabalho do poeta e professor português António Corrêa d'Oliveira
}

\author{
Pedagogies of saudade (nostalgia): the historical \\ formation of consciousness and saudosistas (nostalgic) \\ sensibilities. The life and work of the Portuguese \\ poet and Professor Antonio Corrêa d'Oliveira
}

Durval Muniz de Albuquerque Junior*

\section{Resumo}

Baseado no fato de que o aprendizado da história, de que o conhecimento de versões sobre o passado não se dá apenas no interior da instituição escolar, que outras pedagogias atuam na sociedade e se utilizam de versões do passado para a formação das consciências e sensibilidades de homens e mulheres, o texto parte da trajetória de vida do poeta e professor português António Corrêa d'Oliveira e se interroga sobre os usos que fez da história não apenas em sua obra, mas em sua vida. O texto tenta mostrar, acima de tudo, como a própria vivência da história, as próprias experiências sociais, culturais e temporais que sofrem os sujeitos conformam dadas maneiras de pensar e lidar com o histórico. Neste caso, mostramos a relação intrínseca entre uma consciência e uma sensibilidade saudosista e dadas maneiras de ensinar e de aprender a história.

Palavras-chave: História; saudade; ensino.

\section{Abstract}

Given the fact that the learning of history, that the knowledge of versions about the past does not happen only within the school institution, that other pedagogies acts out in society and makes use of versions of the past for men and women's formation of consciousness and sensibilities, the text is based in the life trajectory of Portuguese poet and professor Antonio Corrêa d'Oliveira and wonders not only about the uses of history made in his work, but also in his life. The text tries to show, above all, how one's own history, social, cultural and temporal experiences conform the ways of thinking and dealing with the historic. In this case, we show the intrinsic relationship between a consciousness and a saudosista (nostalgic) sensitivity and some ways to teach and learn history.

Keywords: History; saudade (nostalgia); teaching.

\footnotetext{
* Universidade Federal do Rio Grande do Norte (UFRN).durvalaljr@gmail.com
} 
COMO SE APRENDE A SENTIR SAUdADES

"Águas passadas não tornam",

Deixai falar o ditado:

Ó Saudade, és um moinho,

Móis com águas do passado.

D’Oliveira, "Das Cantigas"

\section{a) As formas de se aprender e apreender a história}

O aprendizado da história, o conhecimento do passado, seja de uma dada localidade, seja de um dado grupo social, seja de uma dada nação faz parte, cada vez com maior intensidade, das experiências formadoras das subjetividades de homens e mulheres nas sociedades ocidentais, notadamente a partir do século XIX. Com a disciplinarização desse saber e sua inserção no currículo escolar, à medida que a educação formal das elites sociais se dá cada vez mais no âmbito das escolas, sejam públicas, sejam privadas, o contato com a história ensinada em sala de aula e através de toda uma literatura de cunho didático torna-se um elemento de formação de concepções acerca do tempo, de formas de pensar e entender a história e a própria historicidade e da constituição de sensibilidades atentas e afetadas por essa consciência da historicidade de todas as coisas. $\mathrm{O}$ contato com narrativas sobre o passado, no entanto, não está adstrito aos bancos escolares e não é privilégio apenas daqueles que têm acesso à educação formal. Narrativas que exercem a função de construir um passado para os que vivem no presente, preenchendo assim uma necessidade humana de orientação, de localização no tempo, narrativas fundamentais para a construção das identidades individuais ou coletivas, circulam por todo o social e exercem funções pedagógicas tão importantes quanto as daquelas narrativas que circulam no espaço escolar. Sejam narrativas lendárias, mitológicas, memorialísticas ou propriamente historiográficas, esses discursos oferecem versões para o passado, estabelecem dadas relações entre as temporalidades, favorecem a subjetivação de dados cronotopos, ou seja, maneiras de se conceber o tempo e dados regimes de historicidade, ou ainda, dada maneira de se conceber o histórico, a história e a narrativa do histórico. ${ }^{1}$ Podemos dizer, portanto, que o aprendizado do passado se faz para além da educação escolar 
e que diversas pedagogias atuam no campo social para que cada ser humano realize a aprendizagem do passado e estabeleça com ele uma dada relação, não apenas cognitiva, imaginativa, simbólica, mas também afetiva. Ao apreendermos e aprendermos o passado não apenas temos com ele uma relação racional, mas também estabelecemos com ele uma relação emocional, emotiva, afetiva que - tese que defenderei neste texto - advém muito das próprias condições sociais e pessoais nas quais fizemos esse aprendizado. As condições presentes em que nos achamos ao contatar o passado têm o condão de dar a esse passado dado colorido, dados sentidos e sensações que marcarão indelevelmente a imagem que faremos desses tempos que se foram.

Sabemos que as versões do passado construídas pela historiografia profissional nem sempre são aquelas que chegam à maioria das pessoas que compõem uma dada sociedade, mesmo com o processo de escolarização se generalizando cada vez mais. Toda sociedade dispõe de uma cultura histórica que se compõe de atividades de significação, narrativização, exposição, oferecimento de versões para o passado que em muito excede as ofertas de passado disponibilizadas pelos historiadores. ${ }^{2}$ Maurice Halbwachs adotou o conceito de memória histórica para nomear essas versões da história, esses fragmentos de narrativas sobre dados eventos do passado que se fazem presentes nas memórias individuais e coletivas, muitas vezes servindo de marcos divisores ou orientadores para a construção da narrativa memorialística (Halbwachs, 1990). Atentando para a necessidade de não confundir-se a memória, seja individual, seja a coletiva, com a história, Halbwachs chamava a atenção, no entanto, para a presença de dadas construções narrativas de cunho historiográfico, de retalhos de construções cultas sobre os acontecimentos históricos que circulavam socialmente e eram incorporadas às memórias, vindo a integrar os discursos memorialísticos de cunho individual ou coletivo. Por intermédio de mecanismos de vulgarização e divulgação, nos quais o próprio ensino escolar terá destaque, utilizando os meios de comunicação de massa assim como outros tipos de atividades culturais em que esse material historiográfico aparece retrabalhado - como na literatura, no cinema, na música e até mesmo na propaganda, seja de cunho estatal, governamental, seja de cunho comercial e privado -, retalhos de narrativas historiográficas, versões sobre o passado, construídas, inicialmente, por profissionais, circulam socialmente e são aprendidas pelas diversas camadas sociais. Além de que não podemos ignorar o fato de que os 
historiadores não detêm o monopólio sobre a narrativa e a significação do passado. Mesmo no espaço escolar a história ofertada pelo professor dessa disciplina nem sempre está a par das versões majoritariamente aceitas por aqueles que militam no campo da pesquisa e da escrita historiográfica. Nesse espaço, outros profissionais, como o professor de literatura ou de artes, podem oferecer versões e compreensões distintas do histórico, não só na medida em que ofereçam nas aulas suas próprias leituras da história, mas porque utilizam em seu trabalho textos ou artefatos de arte que podem trazer leituras divergentes sobre o passado.

Mas todas essas formas de elaboração e aprendizagem da história estão mediadas por uma outra maneira de se ter contato com a historicidade, com o histórico, com a história, que é a própria vivência social, cultural e temporal à qual todos os humanos estão submetidos. Não apenas aprendemos a história, mas a experimentamos, a vivenciamos, a sentimos na pele, na carne, na consciência. Não apenas ficamos sabendo da história, não apenas a conhecemos, mas a vivemos, a sentimos. A história nos afeta de dada maneira singular e, por isso mesmo, nos constitui como singularidades. A vida como seres históricos que somos, mesmo que disso tenhamos pouca consciência, o que se torna cada vez mais difícil numa sociedade - como dirá Pierre Nora - que se torna a sociedade da história, substituindo assim as sociedades da memória, nos obriga a, cada vez mais, procurarmos apreender o seu significado (Nora, 1997). A ânsia crescente de todos os grupos sociais de fazer parte da história, de serem vistos e ditos como agentes históricos, processo que ocorre cada vez mais a partir do século passado, como chama atenção Philippe Ariès, faz que a história seja uma presença cada vez mais decisiva e incisiva na produção não só das consciências mas das sensibilidades daqueles que vivem o presente (Ariès, 1989). Cada vez mais a história passa a ser tema de debate, de inquirição, de preocupação, de disputa, de atenção de todos aqueles que vivem em sociedade. No século XX, a chamada grande história invadiu a vida de todos os seres humanos, ninguém passou incólume diante dos grandes genocídios e das grandes tragédias humanas que marcaram o século: a guerra, a revolução, a guerra civil, o processo de independência e de descolonização, a implantação de regimes políticos de cunho totalitário, a crise econômica e os grandes feitos da ciência e da tecnologia chegaram à vida de todos, mesmo que apenas como notícias. O aprendizado da história, de seus sentidos e significados, foi aí 
apreendido; relatos sobre o passado foram aí elaborados. Dadas maneiras de se relacionar com o passado e com o tempo daí advieram.

É dessa primeira forma de se fazer o aprendizado do histórico, é desta maneira de se aprender formas de se relacionar com o tempo e com o passado que pretendo tratar inicialmente neste texto. Lembrando que esse aprendizado feito na própria vida, no dia a dia, leva não apenas à formação de dadas maneira de racionalizar a temporalidade, de explicar o passado, a formação de uma dada consciência histórica, mas também à formação de dadas maneiras de sentir os tempos, de se deixar afetar pelo passado, a formação de uma dada sensibilidade histórica.

\section{b) A dimensão social e histórica da expressão dos sentimentos}

Para tratar desse contato existencial com a história e das formas de consciência e sensibilidade que ele pode originar, para sair da abstração e poder dar concretude histórica ao que estou falando, não me deterei, no entanto, em abordar a vida de um profissional da historiografia, mas a vida de um poeta e professor, a vida de um educador, a vida do que poderíamos chamar de um pedagogo da nação, um homem que dedicou toda a sua vida e a sua obra, que em todas as atividades da qual participou, que em todas as suas iniciativas, visou educar o povo português, notadamente as suas crianças, para as quais dirigiu alguns de seus livros, para as quais veio a fundar uma escola. Educação moral e educação cívica, utilizando-se para isso, muitas vezes, da construção de versões para o passado de sua nação, lançando mão de toda uma série de eventos e personagens da história de Portugal, para daí extrair ensinamentos que pudessem servir de orientação para a ação e para a vida daqueles que pretendia formar através de seus livros, de suas palestras, de suas conferências, de seus artigos em jornais ou revistas, de suas aulas. Adotando ainda a concepção da história como mestra da vida, ele que dizia com ela ter muito aprendido, buscava, em seus acontecimentos, exemplos de moralidade, de civismo, de patriotismo, de amor à pátria, à terra, à família, aos valores que definia como inseparáveis do ser mesmo de sua nação.

Estamos falando do poeta e professor português António Corrêa d'Oliveira, que talvez hoje poucos brasileiros conheçam, mas que só para dar uma ideia de sua importância e centralidade na vida cultural de Portugal, e por 
que não dizer na literatura de língua portuguesa, foi o primeiro português a ser nomeado para o prêmio Nobel de literatura, em 1933, sendo o escritor português com o maior número de nomeações, cerca de 15 vezes. Como veremos, posteriormente, essas nomeações muito se deveram a sua aproximação com o Estado Novo português e por gozar da simpatia do regime salazarista, o que não quer dizer que sua obra literária não tivesse qualidade. Além disso, ele foi personagem importante nas relações culturais mantidas entre Portugal e o Brasil quando da vigência do Acordo Cultural celebrado pelos governos de Salazar e Getúlio Vargas. Entre 9 de junho e 10 de julho de 1937, esteve no Brasil a convite da Federação das Associações Portuguesas do Brasil para participar das comemorações do centenário do Real Gabinete Português de Leitura e participar das homenagens a Luís Vaz de Camões que estavam sendo realizadas por aquela entidade. Tendo raízes familiares no Brasil, António Corrêa d'Oliveira já era um poeta conhecido entre as elites literárias brasileiras desde o final do século XIX, tendo sido eleito membro correspondente da Academia Brasileira de Letras desde o ano de 1909 (Rocha, 1960; Durão, 1961; Magalhães, 1960).

Sendo considerado pelos críticos literários como um poeta neogarretista, em referência ao grande nome da poesia romântica portuguesa, Almeida Garrett, António Corrêa d'Oliveira seria um neorromântico, ou seja, um poeta onde predominava a sentimentalidade, a dimensão e a visão subjetiva da existência, acompanhada de uma recusa, de um estranhamento em relação ao tempo presente, à sociedade moderna, à sociedade burguesa, urbana, industrial. Sua adesão, em 1912, ao movimento Saudosista, que se organiza em torno do grupo da Renascença Portuguesa, da revista A Águia e das figuras de Teixeira de Pascoaes e Leonardo Coimbra, diz muito sobre sua maneira de se relacionar com o tempo, da sua maneira de conceber o histórico, de conviver com a historicidade das coisas, de apreender o que vivenciava, sendo também significativa para entendermos que visão da história, que relação com o tempo irá emergir em seus escritos e em todas as atividades intelectuais que realiza. Podendo ser considerado um saudosista, a vida e a obra de António Corrêa d'Oliveira podem nos servir de material de análise no sentido de entendermos como no momento histórico em que viveu e, mais precisamente, no momento em que se deu a sua formação, foi possível emergir consciências e sensibilidades marcadas pela saudade do passado. Sua formação e aquilo que escreveu 
nos permitem investigar que acontecimentos históricos, que experiências foram condições históricas de possibilidade para que se formassem subjetividades reativas ao presente, à história, ao passar do tempo, ao mundo que as rodeavam e, mais importante, avaliar que concepções políticas, éticas e estéticas foram resultado dessas subjetividades ancoradas na saudade, quais os desdobramentos em termos de práticas discursivas e não discursivas tiveram, como elas se materializaram em obras literárias, artísticas, mas também em ações políticas e institucionais. E, no que nos interessa mais de perto neste texto, como esses sujeitos saudosistas pensaram, escreveram e ensinaram a história, que visões e versões do passado foram oferecidas pelas obras deixadas por autores com essa dada forma de consciência e sensibilidade.

Marcel Mauss, ainda no começo do século XX, já havia contestado a visão de que os sentimentos seriam objeto de estudo exclusivo dos psicólogos, de que eles seriam manifestações puramente individuais, solipsistas, que aconteceriam no interior de um Eu fechado, monádico, expressões naturais de um corpo ou quase secreções de uma alma ou de um espírito autônomos. Em seu texto “A expressão obrigatória dos sentimentos" ele vai afirmar o caráter social e coletivo dos sentimentos na medida em que eles, para serem expressos, obedeceriam a códigos, a regras, a rituais que seriam socialmente e culturalmente produzidos (Mauss, 1979). Os sentimentos poderiam ser objeto de estudo das ciências sociais e históricas porque, embora fossem considerados parte da natureza humana, tendo assim um grau de universalidade e generalidade em toda espécie, deixavam de ser simples reações instintivas ou animais na medida em que os homens viviam em grupo, mantinham relações sociais que levavam à ritualização, à codificação, ao regramento, à repressão e limitação das expressões sentimentais. Expressar um sentimento significa conseguir comunicá-lo a um Outro, fazer passar algum sentido através dele para um outro observador. Os sentimentos implicam assim a elaboração de uma linguagem, seja mímica, seja gestual, seja icônica, seja falada ou escrita. Os sentimentos são inseparáveis daquilo que Erving Goffman chamou de teatralidade da vida social (Goffman, 2001). Nos tornamos sujeito, como defende toda a tradição fenomenológica, a partir do olhar do Outro. O ser sujeito implica assumir uma posição, uma postura, uma máscara, uma performance cultural e socialmente elaboradas, em dado tempo e espaço específicos diante de um Outro. É no cruzamento de olhares e de dizeres, de imagens e textos, sejam escritos ou não escritos que os 
sujeitos se enformam, que constroem imagens de si e para si (Merleau-Ponty, 2013). A saudade, como todo sentimento, implica a elaboração de uma linguagem que a expresse, implica a escolha, a eleição de gestos, de enunciados, de mímicas, de performances, de imagens, de ações e reações que lhe deem materialidade, realidade e espessura social e histórica. A saudade não basta ser sentida para existir, ela deve ser, antes de tudo, conceituada como tal, deve ser nomeada, chamada de saudade e materializada em gestos, ações, reações, performances. Além disso, os sentidos agregados à palavra saudade - seu universo semântico, seu feixe significativo, a constelação de sentidos trazidos por este conceito quando pronunciado - variam de época para época. Por isso, sentir saudade nem sempre significa sentir a mesma coisa, e nem sempre o que se sentiu como saudade em dado tempo e sociedade continua sendo saudade em tempos e espaços diversos. Aliás, como esse conceito é específico da língua portuguesa, é um sentimento específico dos povos que falam essa língua, sem ignorar que o sentir falta, o sentir tristeza ou melancolia pela falta, pela ausência de algo ou alguém, seja um sentimento partilhado por todos os humanos; mas, ao serem nomeados com outros conceitos, outros sentidos adquirem. Além disso, o sentir saudade implica adotar uma dada gramática de gestos, de práticas, de reações, de comportamentos, mas também dado conjunto de enunciados e imagens que estão social e culturalmente a ela ligados em um dado contexto. Portanto, o que se pretende neste texto é não só entender como se forma uma dada consciência e uma dada sensibilidade saudosa, mas também como se diz e se pensa, como se materializa em ações políticas, éticas e estéticas essa visão saudosa do mundo, como a saudade é conceituada e enunciada nos escritos de um dado sujeito específico e como esse ser saudoso implica uma dada maneira específica de se relacionar com o passar do tempo, com o passado e com o presente, como ela direciona dadas ações na direção do futuro e como ela traz consigo uma forma de conceber o histórico, uma dada relação com a história. Como esse sujeito saudoso, essa subjetividade saudosista foi produto de um processo de aprendizado, de educação da consciência e da sensibilidade que se deu tanto na escola como na vida, e é possível analisar que pedagogias estiveram atuando para a formação desse sujeito histórico ancorado na saudade. 
A análise de alguns traços biográficos do poeta António Corrêa d'Oliveira nos permitirá tentar responder à seguinte pergunta: como se aprende a sentir saudade? Se os sentimentos não são naturais, se eles implicam o aprendizado de códigos, de regras, de performances, de linguagens, de sentidos, o sentir saudade também nasce de um aprendizado, de uma experiência, de uma formação que sempre será social e cultural, mas que também é histórica na medida em que se dá num dado tempo e num dado espaço específicos. António Corrêa d'Oliveira aprendeu o que é saudade, apreendeu antes de tudo um conceito, mas um conceito que era datado e localizado, aprendeu a sentir, pensar e expressar a saudade na medida em que vivia em um dado tempo e espaço. Aprendeu ouvindo outras pessoas dizerem o que sentiam como saudade, aprendeu vendo as pessoas a seu redor expressando suas saudades, aprendeu lendo escritos que definiam e descreviam a saudade, o ser saudoso, aprendeu vendo imagens nomeadas e significadas com base no conceito de saudade, aprendeu vivendo experiências de perda, de ausência, de luto, aprendeu com as ruínas que a passagem do tempo acumulava à sua volta os significados e sentidos que seu meio e sua época atribuíam a esse sentimento. Recuemos então para o último quarto do século XIX, prestemos atenção ao que se passava na sociedade portuguesa naquele momento, focalizemos Portugal, mais especificamente a realidade interiorana desse país. Nesse tempo-espaço nasceu e se formou o sujeito António Corrêa d'Oliveira, o poeta que depois se dirá saudosista. Como essa ambiência favoreceu a formação dessa modalidade de consciência e de sensibilidade?

\section{c) Pedagogias do sofrimento: o doloroso aprendizado da saudade}

António Corrêa d'Oliveira nasceu a 30 de junho de 1878 na vila de São Pedro do Sul, distrito de Viseu, na Beira. Tem origem, portanto, numa pequena aldeia do interior de Portugal, sendo descendente da aristocracia rural, que via sua importância política e econômica diminuir desde meados do século XIX. Neto de António Corrêa d'Oliveira, o "Corrêa Velho", homem de grande prestígio político e de grande fortuna (era dono de sete quintas na Beira Alta, Trás-os-Montes e Douro), viu a fortuna da família declinar, pois, embora tenha nascido quando seu pai ainda possuía muitas posses, na adolescência, por volta dos seus 12 anos, a família já vivia em sérias dificuldades financeiras, que se 
tornam pobreza no momento em que o pai vem a falecer (Simões, 1980; Ramos, 1987). Creio que aqui encontramos alguns acontecimentos, algumas experiências traumáticas, vividas no tempo presente, que podem ter sido decisivas para a formação de uma consciência e uma sensibilidade marcadas pela saudade, como era a do poeta e professor, para a formação de uma visão de mundo marcada pela nostalgia do passado, de um passado de glórias, de fausto, de riqueza, de poder e de prestígio, que tinha sido o passado de sua família, de seus avós, daqueles de sua classe social, agora em franco processo de decadência trazido pelas mudanças históricas em curso no seu país. Seu aprendizado da história se faz mediante essa dolorosa história familiar e individual, pela história de declínio da aristocracia rural portuguesa que estava conectado ao processo histórico mais amplo vivido pela sociedade portuguesa, que era de crise política, econômica e institucional. Os dissabores e traumas que essa situação familiar lhe acarreta, contribuindo para que se tornasse um homem doente e sensível, aciona pedagogias que vão atuar não apenas sobre seu corpo, mas sobre sua consciência e sensibilidade. Os anos 1870, no final dos quais nasceu o poeta, marcam a intensificação da crise vivida por Portugal, crise que leva ao adensamento do processo emigratório, que leva milhares de portugueses a abandonar seu país. Podemos dizer que o menino António Corrêa d'Oliveira experimenta, vê com seus olhos o desmoronar do mundo rural tradicional de Portugal. Vivencia os últimos resquícios da sociedade feudal que estão sendo destruídos pela intensificação das relações capitalistas no campo e a subordinação definitiva do país aos ditames do capitalismo industrial e imperialista, como uma área periférica e subordinada. O esvaziamento do campo, a quebra dos laços tradicionais de trabalho, de troca de favores, de compadrio, de vizinhança, a saída em massa de grande parte da população que habitava os campos em direção às maiores cidades ou a outros países, instauram a saudade não apenas como um tema presente em todas as conversas, nas correspondências, nas produções culturais do período, como se tornam mesmo a condição existencial da grande maioria dos portugueses. Todos, sejam ricos, pobres ou em declínio social convivem com e sentem saudades. Creio que o menino António Corrêa d'Oliveira aprendeu a sentir saudade com sua parentela, que deveria lhe contar, agora quase como um conto de fadas, a época de apogeu, o passado de distinção, poder e riqueza de que já haviam desfrutado. A figura do avô, descrito como homem muito estimado e respeitado por todos, 
aparecia aos olhos desse menino quase como uma figura lendária, como um modelo de ser homem, de ser masculino, de ser português que marcará a construção de sua própria subjetividade. Esse avô encarnava valores, costumes, tradições, formas de pensar e estar no mundo que eram agora praticamente inatuais, constituindo um passado que em cotejo com o presente de declínio e de dificuldades em que o adolescente - e, mais tarde, o homem adulto - vivia aparecia como muito superiores. Ao sentir saudade do passado, ao sentir saudade de seu avô que morrera quando era ainda muito criança, ao sentir saudade de um Portugal que ficara perdido em sua infância, o poeta expressa também a saudade de uma dada ordem social que veio a sucumbir diante da modernidade capitalista, da sociedade burguesa, cada vez mais presentes e dominantes em seu país. ${ }^{3}$

O poeta e professor António Corrêa d'Oliveira teve de conviver desde os 12 anos de idade com o vazio deixado pela morte de seu pai, ausência que veio acompanhada da intensificação das dificuldades financeiras da família. Seu pai, que fora Deputado da Assembleia Nacional, que fora chefe político do Partido Regenerador em São Pedro do Sul, correligionário do líder político nacional Hinze Ribeiro, que fora amigo do escritor e poeta Camilo Castelo Branco, se foi, deixando sete filhos órfãos e uma esposa assoberbada de responsabilidades e tendo de lidar com muitas dívidas e poucos recursos. A presença paterna transformada em ausência, o amparo e a segurança que se transformam em desamparo e em insegurança talvez tenham sido experiências decisivas para a formação da subjetividade saudosista que será a marca da vida e da obra do poeta. A experiência da orfandade paterna numa sociedade em que o pai ainda constituía a figura central, o sustentáculo da própria vida familiar, a momentânea desestruturação familiar que ela ocasionou deve ter produzido naquele menino a forte recusa do presente e o medo constante do futuro que vai manifestar-se nas atitudes e nos escritos do adulto. Seu apego ao passado, sua idealização de uma época anterior àquela em que havia vivido sua infância, parecem estar associados a essa traumática experiência de perda, de luto, que vivenciou ainda entrando na adolescência, perda e luto que se estendiam do plano individual para o plano coletivo, social, já que a perda do pai veio acompanhada de outras perdas partilhadas com muitos outros de sua condição social. Perdas individuais e debacle social parecem se articular e explicar como 
o poeta e outros homens e mulheres de sua geração e de seu país aprenderam a sentir saudade.

A mãe, d. Joaquina Augusta, diante da situação econômica em que se encontrava, fecha a casa da Ponte - elegante sobrado aristocrático na vila de Viseu, solar avoengo, chamado de lugar de Anciões porque ali viveram algumas gerações de sua família, casa onde crescera o menino - e vai viver com os filhos numa pequena moradia rural, na Quinta da Caldeiroa, próximo a parentes que passam a lhe dar ajuda na criação dos filhos. Somam-se, assim, as experiências de perda: fica para trás o sobrado aristocrático, símbolo de poder e riqueza da família, fica no passado a vida no Viseu, as companhias de infância, todo o mundo que conhecia desaparece para que uma nova e desconhecida realidade se instaure. Sabemos que o sentir saudade está intimamente ligado a eventos marcados pela perda, pela ausência, pela mudança que não se deseja, pelo desaparecimento ou distanciamento de algo ou alguém com que se tem laços afetivos e existenciais. Esse processo de desterritorialização subjetiva, essa experiência de desarraigo, de perda de seu lugar existencial, de seu lar, de territórios construídos vivencialmente vai produzir uma idealização desses espaços e desse tempo que antecedem ao que seria visto como queda, que serão guardados na memória como fragmentos de espaços-tempos de bonança e felicidade, e que reaparecerão como reminiscências e lembranças em toda sua produção poética, marcada pelas dores e tristezas que passou a vivenciar no seu presente. Num poema de seu livro significativamente nomeado de Alívio dos tristes, lembra nestes termos a sua mãe: "Pois minha mãe a vejo e sempre hei visto/ tão ralada de penas e tormentos/ Que até parece Jesus Cristo" (D’Oliveira, 1918, p.10). Refere-se à ruína da família: "Outros vivem na casa de meus pais/ Campos que foram meus já não o são/ Outros, que ainda o são, não serão mais...” (ibidem, p.15). O tom saudosista aparece sempre que se refere ao tempo que precedeu a essa experiência de queda ou a esse calvário, não apenas materno, mas também pessoal. Em carta escrita em 1907, desde Sevilha, a Maria Amália Vaz de Carvalho, diz:

E as festas (Páscoa) não começavam nunca sem que meu avô, um velhinho adorado pelo povo, ou meu pai, o filho querido, entrassem na Igreja e tomassem lugar nas altas cadeiras do Altar-Mor. ${ }^{4}$ 
Em sua subjetividade vão se amalgamando várias saudades: a saudade de sua casa, de sua terra, de seu avô, de seu pai, da situação de abastança e de prestígio em que vivera junto aos seus, dos costumes ditos tradicionais que iam ficando para trás, das relações sociais, da ordem social que ia se esboroando. Por causa da situação de pobreza em que passam a viver vê também a partida de seu irmão mais velho, Amadeu, para tentar a sorte no Brasil, de onde retorna sem nada ter conseguido, vindo a falecer pouco tempo depois, ainda jovem. A emigração, o tentar a sorte no Brasil, a necessidade de abandonar a terra, a família, a partida como única esperança e alternativa de vida, que era uma realidade na vida da maioria das famílias portuguesas nesse fim de século XIX de falência financeira do país, da humilhação nacional que foi o ultimato inglês de 1896, também foram vivenciados de perto pelo futuro poeta e professor. A perda por duas vezes de seu irmão mais velho, aquele que seguindo a tradição de uma família patriarcal ficara no lugar do pai ausente, que deveria assumir a responsabilidade pelo provento da casa e que, por isso mesmo, tivera de tentar a sorte no Brasil, de onde retorna fracassado e doente, deve ter sido mais uma experiência marcante para a formação de uma subjetividade dominada pela saudade, como a do poeta António Corrêa d'Oliveira. A relação entre saudade e viagem, tão fortemente estabelecida na cultura portuguesa desde o período das grandes navegações, em que as famílias viam seus entes queridos deixarem as barras do rio Tejo em caravelas que levavam a aventuras, à busca de terras distantes e desconhecidas, de onde não havia nenhuma certeza de que voltariam, se reforça nesse final do século XIX, onde é reencontrada no processo de emigração de grande parte da população para outros países, em busca do trabalho e dos recursos que não encontram na terra natal. Esse drama coletivo da partida de pessoas com as quais se mantêm vínculos afetivos e existenciais parece dar origem a uma espécie de luto coletivo, pois a presença da morte nessas viagens era também uma constante. Essas experiências que eram, ao mesmo tempo, individuais e sociais, constituíam, podemos dizer, uma verdadeira escola de como sentir saudade, elas nos parecem mobilizar verdadeiras pedagogias do sentir saudoso.

A experiência escolar de António Corrêa d'Oliveira também pode ter sido formadora de sua subjetividade saudosista. Ele fez os estudos primários em São Pedro do Sul com o Sr. Barros. Com o apoio dado por um irmão de sua mãe, Fortunato de Almeida, que era abade, concluídos os estudos primários, 
pôde abandonar a casa materna para estudar interno no Seminário do Viseu. Mais uma experiência de perda e desarraigo, uma experiência tão dolorosa que ele só a suportou por um ano. Aludindo falta de vocação religiosa, retorna para São Pedro do Sul. Por falta de condições econômicas, nunca completará sua formação escolar, não conhecerá títulos de bacharel, nem diplomas, nem os bancos da Faculdade de Direito de Coimbra para onde se dirigiam, no passado, os membros varões de sua família. Não poderá seguir a trajetória feita pelo pai, que fora o orgulho de seu avô, o qual nele investira todas as suas esperanças e todo seu capital simbólico e econômico. Mas essa breve experiência escolar e, talvez, seu insucesso e ausência posterior, podem ter trazido duas marcas importantes em sua consciência e em sua sensibilidade: o reforço de suas convicções religiosas, cristãs, tornando-o um crente numa época marcada pelo declínio do sagrado, pela laicização da sociedade e do Estado, pelo afastamento das elites intelectuais e científicas das aras da religião, pela dessacralização do mundo e, inclusive, da educação, no dizer de Max Weber, pela temática da "morte de Deus" como a nomeará um influente pensador de seu tempo: Friedrich Nietzsche. ${ }^{5}$ Sua religiosidade o fará um homem reativo a esse presente marcado, segundo ele, pelo materialismo, pelo utilitarismo, pelo abandono e desprezo das coisas transcendentes. Muitas de suas posturas políticas e estéticas posteriores estão relacionadas com essa formação religiosa e católica, que nunca renegará, embora viva momentos de dúvida e tentações panteístas. O fracasso escolar, a dificuldade em acessar o mundo das letras e a educação formal fazem dele, em grande medida, um autodidata e, ao mesmo tempo, aprofundam a consciência da debacle social de sua família.

Será justamente a dedicação às letras, à poesia, que cedo aparece em sua vida, quando tinha apenas 16 anos, que o fará ocupar um lugar de destaque, recuperar o prestígio que sua família havia perdido. Ao lado do trabalho em repartições públicas, em empregos obscuros e rotineiros, conseguidos às custas das relações familiares e do capital político e social que sua parentela ainda possuía, pois tinha receio de se submeter a concursos públicos, justamente por sua deficiente formação escolar, vai desenvolver sua carreira literária, marcada por sua mirada saudosa e passadista, muito dela resultado da condição de desprestígio social em que se via mergulhado. Ao lado do emprego de amanuense, que passa a exercer em sua vila junto ao irmão João Corrêa d'Oliveira, que também virá a se tornar um importante intelectual e escritor português, escreve 
versos, que ele mesmo descreve assim: "E com isso, meu Deus, me entristecia!/ Era pequeno, então, mas fiz uns versos/ Que faziam chorar sempre que lia...” (D’Oliveira, 1918, p.43). Em 1898 se emprega em Sesimbra como cobrador de impostos dos pescadores artesanais, mas se apiedava deles, deixava de cobrar-lhes o que deviam e, às vezes, pagava do próprio bolso o que devia ser arrecadado. É ainda mediante o recurso às relações pessoais, características de uma sociedade ainda marcada pelo apadrinhamento, pelo paternalismo, pelo nepotismo, uma sociedade onde a pessoa ainda prevalecia sobre o indivíduo, que consegue a nomeação como amanuense na secretaria do Ministério dos Negócios Eclesiásticos e de Justiça, em 15 de junho de 1902. O conselheiro António Ribeiro da Costa intercede junto ao ministro da pasta, José Maria de Alpoim, a pedido da poetisa Maria Amália Vaz de Carvalho, que António Corrêa d'Oliveira conhecera no ano anterior, 1901, quando sob o patrocínio do poeta e crítico literário Trindade Coelho passa a residir em Lisboa e a frequentar o salão literário da casa da Travessa Santa Catarina, presidida pela poetisa.

A última grande perda, o último grande trauma vivido, agora, por um adulto de 32 anos e que terá, a meu ver, participação decisiva nas posturas políticas que irá abraçar, a partir de então, será a queda do regime monárquico em 1910. O poeta estava ligado não apenas por laços familiares e políticos ao antigo regime, do qual participaram, com destaque, seus antepassados. Ele tinha, especialmente, com a rainha d. Amélia laços afetivos e dívidas por favores prestados, em momentos decisivos de sua vida. Foi para ela que o jovem de 17 anos publicou, pela primeira vez, um poema de sua lavra. Em 1896, quando a rainha passou pela vila de São Pedro do Sul em direção às termas de Caldas de Banho, o jovem súdito lhe entrega, de joelhos, uma plaquete com a reprodução dos versos em sua homenagem que havia feito e publicado no jornal Comércio de Vizeu, versos que chamarão atenção para sua veia poética e que o tornarão uma celebridade instantânea em sua terra. Mais tarde, em 1902, quando já se encontrava em Lisboa, tendo sido diagnosticado como anêmico, como candidato a tuberculoso, duramente impactado pela possível perda de sua quinta em São Pedro do Sul, que se encontrava hipotecada, tem seu caso comentado em palácio pelo Conde de Arnoso, em almoço no Paço, o que leva a rainha a recordar-se de seu jovem súdito poeta e a se interessar pelo seu caso, colocando seu médico particular à sua disposição. O Dr. António de Lancastre o diagnostica como neurastênico, com poucas lesões pulmonares, e recomenda 
viagem de cura de três meses pelo sul da Espanha e norte da África, viagem que é inteiramente custeada pela rainha. Embora essa pareça ser uma experiência prazerosa, para António Corrêa d'Oliveira ela foi vivida como um verdadeiro exílio. A correspondência que envia para os amigos deixa entrever o medo constante da morte, só aplacada por sua religiosidade, correspondência em que se esmera em descrever os dias que passam lentos e tediosos, cismando e lembrando dos amigos e parentes deixados em Portugal, onde parecem misturar-se angústia, dor e saudade. Suas outras várias viagens e ausências forçadas motivadas pela necessidade de frequentar ares que favorecessem a melhoria de sua saúde são também escolas de sentir-se saudade. A saúde e a saudade, palavras que guardam parentesco etimológico, a saudade que já fora, inclusive, definida, no passado, como um mal da alma, uma paixão ou moléstia do espírito, voltam a se encontrar e formar par na vida desse poeta. É essa rainha benemérita que ele vê trespassada de dor, ao chegar ao Terreiro do Paço, onde iria esperar a chegada da Família Real, que regressava de Vila Viçosa, na tarde-noite do dia $1^{\circ}$ de fevereiro de 1908, debruçada sobre os cadáveres de seu marido e de seu filho que acabavam de ser assassinados. Se chega dois segundos antes teria presenciado os disparos que vitimaram o rei d. Carlos e o príncipe herdeiro d. Luís Felipe, episódio que iniciou o processo definitivo de dissolução do regime monárquico no país. Ver sua benemérita partir para o exílio, em 1910, e ter o seu emprego no Ministério ameaçado por sua simpatia pelo regime decaído, precisando mais uma vez recorrer a amigos para manter sua única fonte de renda, reforçam suas conviç̧ões monarquistas e fazem dele um inimigo de primeira hora daquela República que, para ele, nascia marcada pelo sangue, pela dor e pela injustiça infringida a um ser superior, como a sua amada rainha. Seu saudosismo existencial e estético se tornam reacionarismo político, levando-o a apoiar movimentos como o Integralismo Lusitano e ser um entusiasta de primeira hora do golpe de Estado que em 1926 dará início ao regime que terá em António Salazar a figura de destaque e a liderança inconteste. A queda do regime monárquico é, portanto, um acontecimento coletivo, mas também individual, uma experiência de perda pessoal e afetiva para o poeta. Em carta a Antero Figueiredo se refere ao sentido presente na publicação por ele de um conjunto de poemas em formato de folhetos populares que nomeou de "Na Hora Incerta" (D’Oliveira, 1927) para referir-se aos anos que se seguiram ao surgimento da República. Diz ele: 
Só a Monarquia convém à felicidade de Portugal. Ora, neste pensamento de Amor, neste movimento de luso instinto, sempre crescente, certo é que, - há meia dúzia de anos a esta parte, à roda da publicação dos folhetos da "Hora Incerta" - o meu Nacionalismo, o meu Monarquismo tem-se avolumado tanto. ${ }^{6}$

\section{COMO SE ENSINA A SENTIR SAUDADES}

\section{a) Nasce o pedagogo da nação}

Essa decisão de veicular seus poemas, numa hora politicamente decisiva da história do país, no formato de folhetos populares, deixa entrever o caráter que o poeta António Corrêa d'Oliveira queria dar à sua produção literária, à sua obra. Ele quer fazê-la acessível à população, quer que as ideias que ela contém acerca da "hora incerta" que a nação vivia tivessem uma audiência ampliada, para além do restrito círculo dos leitores da literatura dita erudita. António Corrêa d'Oliveira assume, como muitos outros intelectuais do pós-Primeira Guerra Mundial, o lugar de pedagogo da nação, de educador das massas, notadamente daquela população que vivia nas grandes cidades, que o poeta via como embrutecida, manipulada pela vida político-partidária da democracia liberal burguesa, caracterizada pela demagogia, pelo panfletarismo, pela radicalização do embate ideológico, pelo vazio de ideias, pelo rompimento ou pelo desrespeito em relação aos valores e costumes tradicionais do país, pela importação de ideias e projetos políticos. A crise subjetiva, da qual ele mesmo fora vítima, entre o fim do século XIX e as primeiras décadas do século XX, com o crescente prestígio das ciências naturais, com o declínio entre as elites intelectuais do país das ideias religiosas, existindo uma verdadeira hostilidade em relação à Igreja católica em razão do papel que exercera de principal instituição de sustentação do regime decaído, a voga de formas de pensamento como o positivismo e o social-darwinismo, de ideologias políticas como o anarquismo e o comunismo, a presença, em sua própria obra, de uma visão panteísta da natureza e do mundo, o que vai aproximá-lo e torná-lo amigo dileto do poeta Teixeira de Pascoaes, por intermédio de quem torna-se militante do movimento Saudosista, membro da Renascença Portuguesa e colaborador da revista A Águia, leva a que tome a decisão de dedicar sua obra a restaurar os valores tradicionais que estariam sendo ameaçados, a tornar seu 
trabalho no campo da literatura como uma atividade pública de educação das massas, de recuperação das camadas populares para as ideias e tradições nacionais em vias de desaparecimento. ${ }^{7}$

Tendo a sorte de encontrar, ainda no início do ano de 1911, aquela que seria a sua esposa para toda a vida, Maria Adelaide da Cunha Sottomayor Abreu Gouveia, reencontra com ela, também, a fortuna perdida, as condições financeiras que lhe permitem abandonar definitivamente o emprego e a situação precária em que vivia em Lisboa. Em 12 ou 13 de junho desse ano parte para as terras que pertenciam a sua esposa, a Quinta do Belinho, também chamada de Quinta das Rosas, na freguesia de S. Paio d'Antas, próxima a Esposende. Embora continue padecendo com uma saúde frágil, que lhe serve de justificativa para o abandono do trabalho, resolve se dedicar à vida de agricultor, a voltar às raízes rurais não só de seus antepassados, mas de seu país, à vida de aldeia, da lide com a terra, com o homem simples do campo, de cuja convivência retira material para sua obra literária. Essa decisão advém da última grande decepção e até humilhação da qual é vítima, quando o Parlamento da República recém-implantada lhe recusa uma nomeação para o cargo de bibliotecário em Mafra, apesar dos esforços do escritor e homem próximo ao regime Júlio Dantas, já que o poeta se recusava a abrir mão de seus princípios, os quais continuava a veicular nas várias obras que vinha publicando. Em 1914, por exemplo, coloca-se contra a decisão do governo republicano português de enviar soldados para a frente de batalha na França, escreve Carta a um Soldado, embora não a torne pública a conselho dos amigos. A esposa administrava a casa e vigiava a lavoura, enquanto ele compunha versos de encomenda e publicava em periódicos espalhados por todo o país. Em 1917, recusa o emprego de professor na Escola Normal do Porto, oferecido por Fidelino de Figueiredo, e na Escola de Belas Artes, oferecido por Antero de Figueiredo, pois o ordenado não compensava o cansaço dos deslocamentos que sua saúde não permitia. A morte prematura do seu primeiro filho, Manoel, para quem compõe o poema "Menino", vem se somar à enorme lista de perdas já presentes em sua vida, tornando-o cada vez mais místico e religioso. Retirado em suas terras, passa a ser apodado de Monge do Belinho. 


\section{b) O ensino público da história nacional}

Mas por que podemos tomar esse poeta como um educador e, mais, como um professor de História? Os temas ligados à história de Portugal sempre estiveram presentes na obra de António Corrêa d'Oliveira. Ele veiculará em suas poesias, em seus escritos e também em suas inúmeras aparições públicas, entrevistas, solenidades em instituições de ensino portuguesas uma dada leitura da história de Portugal, coerente com suas ideias políticas e com sua consciência e sensibilidade saudosistas. Para avaliarmos como no pensamento de Corrêa d'Oliveira se articulam o trabalho artístico, a história, a nação e a saudade, citemos um trecho de uma de suas respostas a um inquérito literário, promovido pelo jornal Diário de Notícias, no ano de 1920. Diz ele:

A árvore para reflorir, afinca as raízes na terra funda. A Arte também é herança do Passado. É ele que nos dá a Saudade, a Lenda, a Tradição. A Saudade, espelho vivo das belas coisas mortas. A Lenda, que parece quase sempre fumo, e muitas vezes é a chama da própria Verdade. A Tradição que - num povo que tem nove séculos - deve ser como uma escada de Job direita à Consciência da Pátria. (D’Oliveira, 6 mar. 1920)

A saudade, a tradição e a lenda, grafadas com iniciais maiúsculas, dando a elas a conotação de entidades metafísicas, elementos que viriam do passado, também elevado à categoria de um personagem, seriam a base para a construção de uma arte verdadeira porque voltada diretamente para atingir a consciência da pátria. Creio que nesse trecho resume-se o ideal artístico de Corrêa d'Oliveira, como ele enxerga a tarefa que executa, ou seja, fazer uma arte que falasse e, por que não dizer, formasse a consciência nacional, utilizando-se para isso dos elementos culturais vindos do passado, presentificados, tornados vivos, embora mortos, pela tradição, pela lenda e pela saudade. A saudade que seria o espelho das belas coisas que haviam morrido. Cristãmente o poeta pensa o seu trabalho como um trabalho de ressurreição, de colocação à frente de seus conterrâneos que viviam a seu lado, no presente, da reapresentação das coisas grandiosas, dos grandes feitos, dos grandes homens, das passagens gloriosas de um povo que já vivia havia nove séculos. Se em seu primeiro livro, intitulado Ladainhas, publicado ainda em 1897, quando contava apenas 19 anos, editado sob os auspícios de seu cunhado Álvaro de Freitas, canta a sua 
terra e a sua gente, canta as saudades nascidas pelas perdas familiares que sofrera desde a infância, livro que o consagrado crítico literário José Francisco Trindade Coelho, responsável pela "Pequena Revista Literária” do jornal $O$ Repórter recepcionou como "o folhear de um missal gótico, ilustrado de iluminuras, lirismo das quadras e romances populares", logo que publica o seu segundo livro torna-se o cantor de um Portugal simples, popular, rural, marinho, pobre, das paisagens de um país em mutação, onde a morte parece atravessar e dar o tom a tudo. Em Eiradas, publicado em 1899, e no terceiro livro - publicado sob o patrocínio do escritor e ensaísta Domingos Guimarães, que se tornou seu cunhado -, O Auto do fim do dia, é a morte lenta de um dado Portugal, é o crepúsculo de uma ordem social, de um estilo de vida, de um passado que se torna seu tema predileto, tudo banhado por um olhar saudoso e nostálgico. Em julho de 1901 retorna às suas vivências de infância no livro Alívio dos tristes, onde, possivelmente, no próprio título dá uma definição da atividade literária a que se dedica, a função que ela ocuparia em sua vida: a escrita como forma de aliviar as dores, uma escrita mediada pela saudade que servia de terapia para as dores que as perdas individuais e sociais que sofrera lhe causavam. A saudade como forma de minorar a ausência querida, de reviver mesmo como um reflexo pálido aquilo já vivido. Mas é a partir de seu rompimento com uma visão panteísta da natureza, tão presente em seus livros Raiz (1903) e Tentação de S. Frei Gil (1907) e da crise pessoal e social provocada pelo fim da monarquia, pela participação do país na Primeira Guerra Mundial, pelas crises políticas sucessivas que o país passa a viver com a instabilidade dos gabinetes republicanos que se sucedem, seguidos de tentativas de golpes de Estado visando a restauração da monarquia ou mesmo a implantação de um regime totalitário apoiado em modelos como o do fascismo italiano, que ele dará a sua obra um nítido caráter cívico, patriótico e didático, trazendo os temas ligados à história oficial de Portugal, notadamente aquela versão forjada pelos defensores da restauração monárquica para o centro de sua obra poética. Acentuando ainda mais o uso de formas poéticas e lançando mão de formatos de publicação de caráter popular, faz de seu trabalho literário um meio de divulgação de sua visão de mundo, de sua leitura do passado, atravessada por um nítido saudosismo em relação à ordem social estamental, aristocrática, ao regime monárquico, à sociedade nobiliárquica, patriarcal, rural, agrária, marcada por relações hierárquicas e pessoais, que constituía o 
passado que elegera como o tempo de sua obra. Nesses livros ensina os portugueses a, assim como ele, sentirem saudades de tempos e realidades de um Portugal que ficara no passado, ajuda através de seus escritos a formar consciências e sensibilidades saudosistas como a sua, preparando o ambiente social para o advento de um regime ditatorial que chegará ao poder em nome da defesa desse passado, dessa tradição, desse Portugal histórico e lendário, em nome da restauração dos tempos gloriosos em que o país pequeno era grande e o país, agora quintal da Europa, era sua sala de visitas. Sentindo-se, como muitos, desenraizado e banido por esse mundo moderno, pela sociedade burguesa, pela vida nas grandes cidades, pelo novo regime político instalado no país, refugia-se na Quinta do Belinho, onde pode reconstruir em seus escritos e, um pouco em sua vida, esse Portugal que via desmoronando, que o leva a cantar as ruínas:

Junto a um velho castelo, aonde estava

A luz crepuscular assim falei:

"Pedras do tempo em que se batalhava

por Deus, por nosso Amor, e pelo Rei:

Como o nosso passado me alembrava, Ao ver-vos! Como agora o desejei!" Mas uma Aparição se alevantava, Ali, de entre as ruínas, e parei...

E disse a Aparição com brando aspecto

Pondo-me então seus olhos piedosos

E suas mãos translucidas no peito:

"Ó triste coração abandonado,

Torre real dos tempos amorosos,

Como também foi lindo o teu passado!"

(D’Oliveira, "Ruínas") 


\section{c) Um professor de saudades}

Dedica-se então à pesquisa do que seriam as tradições do povo português. Já em 1911 publica Dizeres do Povo, baseado em adágios e provérbios populares. E volta-se para aquele público que deveria ser privilegiado nessa tarefa de reerguer o país, de retomar o caminho perdido, de religar o presente ao passado de glórias que se perdia, de educar o povo para amar sua terra e sua história, ou seja, as crianças. Com o livro A alma das árvores, Corrêa d'Oliveira inicia o seu magistério saudosista, torna-se um professor de saudades. Nesse caso, saudade da natureza intocada do passado português, de suas paisagens agora ameaçadas pelo progresso. Ensinar os meninos a amar as árvores, sabê-las possuidoras de almas, almas telúricas, enraizadas na terra, na pátria, era ensiná-los a se verem também como sementes capazes de brotar e tornarem-se frondosas árvores a serviço do futuro do país. Árvores que foram personagens da própria história gloriosa do país, ao se tornarem as caravelas que rasgaram horizontes. Entre 1915 e 1917 publica os dez volumes de A minha terra, na forma de folhetos populares voltados para cantar as virtudes da terra e, principalmente, a sua história gloriosa mesclada a uma visão crepuscular e triste do presente que via de sua janela.

Com o advento do Estado Novo passa de intelectual preterido e sob suspeita a ser um homem festejado e coberto de honrarias. Em 1934, o ministro da Instrução Pública entrega em sua casa as insígnias de Grande Oficial da Ordem de S. Tiago da Espada, como reconhecimento por sua obra pedagógica, pelo seu trabalho de educador cívico da nação. Trabalho que havia sido coroado, no ano anterior, pela criação do Colégio de Belinho, junto à sua casa, onde ele e sua esposa passam a exercer o magistério, ensinando as crianças das redondezas que não tinham ainda acesso ao mundo das letras. Como seu diretor ele assim define o tipo de educação que aí é ministrada: “apelo aos jovens de uma raça de obreiros na fé, defensores de um chão e de uma tradição, baseada na família cristã, regime de internato, educação moral, cívica e física", prestando ainda assistência aos pobres e doentes da região. Não é preciso dizer do caráter conservador que podemos vislumbrar em tal currículo e em tal orientação pedagógica. A história aqui não está a serviço da crítica e da desmitificação do passado mas, ao contrário, mistura-se com o lendário e serve de recurso para a veiculação de uma mitologia nacionalista e patrioteira que tem a função 
de legitimar junto à sociedade o regime de plantão, inculcando as principais formulações ideológicas que o sustentavam, como: a superioridade da colonização portuguesa nos trópicos, o que legitimava o domínio ainda exercido sobre as colônias africanas; o caráter cristão da sociedade portuguesa, exemplo a ser seguido, reserva de fé e de esperança num mundo que havia perdido a crença na divindade e vivia mergulhado na desesperança e no materialismo, ameaçado pelo ateísmo e pelo comunismo; o destino messiânico de Portugal, que ainda haveria de se tornar novamente o farol do mundo, o exemplo a ser seguido pela Europa, quando a decadência de sua civilização burguesa, filistina, mercantil, utilitária, anunciada pelas guerras que enchiam suas ruas de sangue e corpos mortos e mutilados chegasse a seu termo. Em carta a Antero de Figueiredo manifestou nestes termos seu apoio ao salazarismo:

De resto, este governo, representado numa república, tem toda a minha simpatia e apoio moral; bem merece de nós todos - pois a todos livrou de horas horrendas, e a Nação, provavelmente, do segundo cativeiro. ${ }^{9}$

Ao longo dos anos 1930 e 1940 elabora uma série de obras didáticas que são adotadas e lidas em todo o país e até em escolas brasileiras, como é o caso do seu Roteiro de gente moça que foi adotado pelas escolas voltadas para os imigrantes portugueses em São Paulo; Pátria nossa, publicada em 1935, e História pequenina de Portugal gigante, de 1944. O poeta José Régio assim definiu essas obras publicadas por Corrêa d'Oliveira: "O espontâneo e natural - que nos faz amar a pátria por um alargamento de amor à família, à casa, ao palmo de terra onde nascemos, ou que lavramos ou onde sonhamos vir a esperar confortavelmente à morte" ${ }^{10}$ Festejado tanto pela Igreja como pelo Estado como um paladino do renascimento espiritual português, António Corrêa d'Oliveira, proclamado pelo papa Pio XII, em 1955, Cavaleiro Comendador da ordem de s. Gregório Magno, pela sua ação em prol do bem e do progresso da Igreja e da Fé católicas, foi assim reconhecido como um educador do povo português, como agente promotor de dada consciência e dada sensibilidade em relação ao país, à sua história, ao seu passado, um homem que dedicou a sua vida e a sua obra, suas atividades de poeta e professor a ensinar como os portugueses deviam sentir saudades, de que os portugueses deviam sentir saudades e, o mais importante, agiu no sentido de que essas saudades fossem a base da construção no presente de um outro futuro para o país, um futuro 
passado, um futuro que trouxesse de volta os grandes feitos e o espírito, o caráter, a alma da nação que havia se extraviado após o Iluminismo, a Revolução Francesa, a adoção de modelos e ideologias estrangeiras que haviam desvirtuado as verdadeiras tradições do país. Restaurar um dado passado de Portugal, reencontrar um país perdido, cumprir as visões proféticas e messiânicas de um António Vieira, de um Bandarra, daqueles que esperavam pela vinda do Quinto Império, pela volta do rei d. Sebastião, pelo retorno do Encoberto, utilizando para isso os poderes e saberes da Saudade, seria sua missão. Ser um semeador ou um vindimador de saudades para que elas, caídas no solo da pátria, pudessem dar saborosos frutos, ser um pássaro a cantar a noite dos tempos para que viessem raiar novos dias para seu país:

Ó Pátria! O teu Passado:/ - Largo Rio fecundo

Nascido sobre o mundo/ Das fontes aureoladas

Aberta às laçadas/ Na carne palpitante

Dos nossos remotíssimos Avós,/ Quando o corpo seria mais feroz

Mas era mais amante/ e mais cheia de fé e de alegria,

Mais viva a portuguesa,/ Uma alma só de Herói, do que de hoje em dia

Toda a nossa alma escrava, todos nós:

Todo um povo tombado na tristeza/ Da mais vil agonia...

\section{Uma Voz:}

Rouxinol, canta de noite;/ De manhã, a cotovia;

- Portugal! Muda de penas:/ Ergue-te à luz: nasce o dia...

\section{Coro:}

Entre o Passado e o Futuro/ O Presente é escuridade...

- O tempo, faz umas sombras/ Que nós chamamos Saudade.

(D’Oliveira, “Os Vindimadores")

\section{REFERENCIAS}

ARIÈS, Philippe. O tempo da História. Rio de Janeiro: Francisco Alves, 1989.

CALAFATE, Pedro. História do Pensamento Filosófico Português. O século XX (Volume V - Tomo 1). Lisboa: Editorial Caminho, 2000. 
CATROGA, Fernando; CARVALHO, M. Archer de. Sociedade e Cultura Portuguesa. II. Lisboa: Universidade Aberta, 1996.

D’OLIVEIRA, António Corrêa. Alívio dos Tristes. 2.ed. Paris-Lisboa: Aillaud e Bertrand; Rio de Janeiro: Francisco Alves, 1918. p.20.

Das Cantigas. In: . Raiz (1898-1903). Coimbra: França Amado, 1903. Inquérito literário. Diário de Notícias, Lisboa, 6 mar. 1920, p.2. . Na hora incerta ou a Nossa Pátria. 10v. Lisboa: Tipografia Elite, 1927. Os Vindimadores. In: . Auto das Quatro Estações. Lisboa: Cernadas \& Cia., 1911. p.141.

. Ruínas. In: Raiz (1898-1903), p.29.

DURÃO, Paulo. António Corrêa de Oliveira. Braga: Gráfica Pax, 1961.

GOFFMAN, Erving. A representação do eu na vida cotidiana. Petrópolis (RJ): Vozes, 2001.

GUMBRECHT, Hans Ulrich. Modernização dos sentidos. São Paulo: Ed. 34, 1998.

HALBWACHS, Maurice. A memória coletiva. São Paulo: Vértice, 1990.

HARTOG, François. Regimes de Historicidade: presentismo e experiências do tempo. Belo Horizonte: Autêntica, 2013.

LEVENE, Ricardo. La cultura histórica y el sentimiento de nacionalidad. Madrid: Espasa-Calpe, 1942.

MAGALHÃES, António. António Corrêa d'Oliveira. Lisboa: Brotéria, 1960.

MATTOSO, José. História da Vida Privada em Portugal. 3. A época contemporânea. Lisboa: Temas e Debates, 2011.

. História de Portugal. VI - A segunda fundação (1890-1926). Lisboa: Editorial Estampa, 2001.

MAUSS, Marcel. A expressão obrigatória dos sentimentos (rituais orais funerários australianos). In: OLIVEIRA, Roberto Cardoso de (Org.). Mauss: Antropologia. São Paulo: Ática, 1979. p.147-153.

MERLEAU-PONTY, Maurice. O olho e o espírito. São Paulo: CosacNaify, 2013.

NIETZSCHE, Friedrich. O Anti-Cristo. São Paulo: Presença, 1975.

NORA, Pierre. Lieux de Memoire. V. 1 - République, Nation I-II. Paris: Gallimard, 1997.

RAMOS, Lydia Cardoso do Carmo Vieira. António Correia de Oliveira: a busca do "nós" e do "eu". Dissertação (Mestrado em Literaturas Comparadas Portuguesa e Francesa) - Universidade Nova de Lisboa. Lisboa, 1987. 
ROCHA, Bento Coelho da. António Corrêa d'Oliveira: poeta da grei. Lisboa: Academia Portuguesa de Ex-Libris, 1960.

SARAIVA, António José. Para a história da cultura em Portugal. v.II. Lisboa: Gradiva, 1995.

SIMÕES, Manuel. António Corrêa d'Oliveira: poeta religioso. Lisboa: Brotéria, 1980.

SOUSA, Bernardo Vasconcelos e; RAMOS, Rui; MONTEIRO, Nuno Gonçalo. História de Portugal. Lisboa: A Esfera dos Livros, 2012.

WEBER, Max. A ética protestante e o espírito do capitalismo. São Paulo: Pioneira, 1992.

\section{NOTAS}

${ }^{1}$ Para a noção de cronotopo ver: GUMBRECHT, 1998. Para a noção de regime de historicidade ver: HARTOG, 2013.

${ }^{2}$ Para a noção de cultura histórica e sua relação com a construção das nacionalidades ver: LEVENE, 1942.

${ }^{3}$ Para a história de Portugal nesse período ver: MATTOSO, 2011; 2001; e SOUSA, 2012.

${ }^{4}$ Carta de António Corrêa d'Oliveira a Maria Amália Vaz de Carvalho, Sevilha, 1907, p.7.

${ }^{5}$ Para a temática da dessacralização ou desencantamento do mundo ver: WEBER, 1992. Para o tema da morte de Deus ver: NIETZSCHE, 1975.

${ }^{6}$ Carta de António Corrêa d'Oliveira a Antero de Figueiredo, Lisboa, s.d., p.1.

${ }^{7}$ Para uma história da cultura e das formas de pensamento prevalecentes nesta época na sociedade portuguesa ver: SARAIVA, 1995; CATROGA; CARVALHO, 1996; e CALAFATE, 2000.

${ }^{8}$ Citado por RAMOS, 1987, p.147-148.

${ }^{9}$ Carta de António Corrêa d'Oliveira a Antero de Figueiredo, Quinta do Belinho, s.d., p.1.

${ }^{10}$ Citado por RAMOS, 1987, p.130.

Artigo recebido em setembro de 2013. Aprovado em outubro de 2013. 